\title{
Barbatiman and chitosan creams as adjuvants in rabbit skin wound healing
}

\section{Cremes de barbatimão e quitosana como adjuvantes na cicatrização feridas cutâneas em coelhos}

\author{
Caroline Rocha de Oliveira Lima ${ }^{1}$; Luiz Antônio Franco da Silva²; Rogério Elias \\ Rabelo $^{3 *}$; Valcinir Aloísio Scalla Vulcani ${ }^{3}$; Bruno Moraes Assis ${ }^{4}$; Welber Daniel \\ Zanetti Lopes ${ }^{5}$; Lucas José Santos Mascarenhas ${ }^{6}$; Rhavilla Santos de Oliveira ${ }^{6}$
}

\begin{abstract}
In this study, $5 \%$ barbatiman and $5 \%$ chitosan creams were evaluated as adjuvants in the tissue repair process by secondary intention of rabbit's skin wounds. Four equidistant wounds were induced in the dorsal skin of 20 adult male rabbits, which were submitted to healing by secondary intention and treated with $5 \%$ chitosan cream (QC, $n=5), 5 \%$ barbatiman cream $(\mathrm{BC}, \mathrm{n}=5), 2 \%$ allantoin cream $(\mathrm{n}=5)$, and base cream $(n=5)$. The creams were applied with the aid of disposable spatulas after washing the wounds. The wounds were daily analyzed by clinical examination for 21 days and histological analyses were performed on the $3^{\text {rd }}, 14^{\text {th }}$, and $21^{\text {st }}$ day after induction. The microscopic evaluation of the wounds of all groups showed macroscopic features of the healing process at different time intervals. The QC and $\mathrm{BC}$ treatments helped in the skin repair process in rabbits when compared to the other two treatments. They induced fibroblast activation and early collagen deposition, and modulated re-epithelialization and neovascularization. Thus, it was concluded that $\mathrm{BC}$ and $\mathrm{QC}$ are efficient and economically feasible as adjuvants in the healing process of skin wounds in rabbits.
\end{abstract}

Key words: Chitin. Lagomorphs. Phytotherapy. Tissue repair.

\section{Resumo}

Neste estudo, os cremes de barbatimão a 5\% e quitosana a 5\% foram avaliadas como adjuvantes no processo de reparação tecidual por segunda intenção de lesões cutâneas de coelho. Quatro feridas cutâneas equidistantes foram induzidas na região dorsal de 20 coelhos machos adultos, que foram submetidos a cicatrização por segunda intenção e tratados com creme de quitosana a $5 \%$ (QC, n = 5), creme de barbatimão a $5 \%(\mathrm{BC}, \mathrm{n}=5)$, creme de alantoína a $2 \%(\mathrm{CA}, \mathrm{n}=5)$, e base de creme $(\mathrm{NC} ; \mathrm{n}=5)$. A aplicação de creme foi realizada com o auxílio de espátulas descartáveis e, antes deste, cada ferida foi lavada. As feridas foram analisadas por meio de exames clínicos diários durante 21

${ }^{1}$ Prof ${ }^{a}$ Adjunta, Universidade Estadual de Goiás, UEG, Campus Jataí, Jataí, GO, Brasil. E-mail: carolrochavet@hotmail.com

${ }^{2}$ Prof. Titular, Escola de Medicina Veterinária e Zootecnia, UFG, Regional Goiânia, Goiânia, GO, Brasil. E-mail: prof_ufg.dmv@, hotmail.com

${ }^{3}$ Profs. Ajunto do Curso de Medicina Veterinária, UFG, Regional Jataí, Jataí, GO, Brasil. E-mail: rabelovet@yahoo.com.br; aloisiosv@hotmil.com

${ }^{4}$ Discente do Curso de Doutorado do Programa de Pós-Graduação em Ciência Animal, UFG, Regional Goiânia, Goiânia, GO, Brasil. E-mail: bruno.moraes.assis@gmail.com

5 Prof. Ajunto, Instituto de Patologia Tropical e Saúde Pública, IPTSP, UFG, Regional Goiânia, Goiânia, GO, Brasil. E-mail: wdzlopes@hotmail.com

${ }^{6}$ Discentes do Curso de Medicina Veterinária, UFG, Regional Jataí, Jataí, GO, Brasil. E-mail: lucas.mascarenhas@hotmail.com. br; rhavilla_@hotmail.com

* Author for correspondence 
dias corridos e por análises histológicas no $3^{\circ}, 14^{\mathrm{a}}$ e $21^{\circ}$ dias após a indução. As feridas de todos os grupos apresentaram características macroscópicas correspondentes com os observados no processo de cicatrização na avaliação microscópica nos diferentes intervalos de tempo. Os cremes debarbatimão a $5 \%$ e de quitosana a 5\% ajudaram no processo de reparação da pele em coelhos quando comparado com os demais tratamentos, uma vez que foi fornecida a activação de fibroblastos e a deposição de colagénio no início, e modulada a reepitelização e neovascularização. Concluiu-se que os cremes de barbatimão a $5 \%$ e quitosana a $5 \%$ são eficiente e economicamente viáveis como adjuvante no tratamento do processo de cicatrização de feridas cutâneas em coelhos.

Palavras-chave: Fitoterápico. Lagomorfo. Quitina. Reparação tecidual.

\section{Introduction}

Healing is a complex, systematic, and organized biological phenomenon in response to the impairment of tissue integrity (BARBUL, 2006). It involves three main phases observed over a period of time: inflammatory, proliferative, and collagen remodeling stages (ACKERMAN, 2007). In several instances, the events of each stage overlap, making it impossible to determine the phases in precise periods. This overlapping dynamism is also considered a factor that contributes to the regular evolution of the healing process (KUMAR et al., 2005; LIMA et al., 2012).

The anatomical size and location of the skin make it permanently susceptible to the action of harmful agents that disrupt and damage its architecture, stimulating the healing process (ACKERMAN, 2007). However, at several instances, the body is unable to properly respond to the injury and in such cases, an adjuvant is needed to facilitate the healing process (BARBUL, 2006). Thus, there has been extensive research to improve the healing dynamics (GILBERT et al., 2005; LEE et al., 2009). Chitosan (AFZALETDINOVA et al., 2000) and Barbatiman [Stryphnodendron adstringens (Martius) Coville] (GILBERT et al., 2005) are being researched as potential adjuvants because they not only aid a systematic healing process, but also are also economically feasible.

Chitosan, produced by the deacetylation of chitin obtained from the shells of crustaceans (ABREU et al., 2013), has biological characteristics related to the healing process, especially the activation of macrophages and modulation of the healing dynamics (AFZALETDINOVA et al., 2000). The phytotherapeutic, Barbatiman, is a native species of the Brazilian savannah and its most important active ingredient, tannin is mostly found in the crust of this legume tree (SILVA et al., 2010). Tannin is a phenolic compound with astringent, antiseptic, antimicrobial, and wound healing properties (GILBERT et al., 2005). However, the use of this phytotherapeutic is still linked to popular beliefs and the scientific evidence supporting these uses is very weak. As a result, the research conducted on the use of barbatiman as an adjuvant for the healing process is limited. Thus, the aim of this work was to evaluate the effectiveness of $5 \%$ barbatiman (BC) and $5 \%$ chitosan creams (QC) in the healing process of skin wounds in rabbits.

\section{Material and Methods}

The study was performed between April 2008 and June 2009 in four stages according to the guidelines of the Committee for Ethics in Research of the Goiás Federal University, Goiânia, Brazil (\#39/2008). The first stage involved the processing and standardization of the constituents of the aqueous extract of barbatiman in the Lab for Natural Products Research of UFG's Pharmacy College. Crusts of the barbatiman tree were collected and dried at room temperature and at $70{ }^{\circ} \mathrm{C}$ in a stove, for 24 hours each, and crushed in an electric mill (TE-650 ${ }^{\circledR}$, Tecnal, São Paulo, Brazil). About 30 $\mathrm{g}$ of the powder was homogenized in $900 \mathrm{~mL}$ of distilled water and subjected to decoction at $70{ }^{\circ} \mathrm{C}$ 
for 2 hours. The gross extract was concentrated in a rotary evaporator (Fisatom $802^{\circledR}$, São Paulo, Brazil) and the concentration was calculated in $\mathrm{g} /$ $\mathrm{ml}$. Further, $2 \mathrm{~mL}$ of the extract was added in a beaker of an established mass and stored in drying oven at $105{ }^{\circ} \mathrm{C}$, for 3 hours. This procedure was performed in rejoinder to ensure the homogeneity of the outputs. The sample masses were determined using a digital analytical scale (AL-200 ${ }^{\circledR}$, São Paulo, Brazil) and the weight of the barbatiman dried extract was measured after the calculation of the arithmetic mean of the beaker's weight. The total phenolic and tannin content in the aqueous extract was determined by Hagerman \& Butler method (MOLE; WATERMAN, 1987a, 1987b); the extract was stored in sterile bottles at temperatures between 5 and $8{ }^{\circ} \mathrm{C}$, and sent to a private laboratory (Farmogral, Brasília, Brazil) for quality control analysis including microbiological and organoleptic characterization tests.

The manipulation of the therapeutic formulations was the second stage and the $\mathrm{BC}, \mathrm{QC}, 5 \%$ allantoin (AC), and the $2 \%$ base cream (NC) were prepared in the Farmogral's Laboratory. The BC was manipulated from the aqueous extract standardized early. The constituents of the remaining creams were purchased from the same laboratory. All creams underwent quality control tests for the evaluation of organoleptic characteristics, $\mathrm{pH}$, viscosity, and density of the products, and bottled in sterilized and identified plastic bags.

The third stage included the induction procedure and treatment of the skin wounds in $20 \mathrm{New}$ Zealand adult male rabbits, weighting $1.800 \pm 500$ g. The animals were maintained at $22 \pm 2{ }^{\circ} \mathrm{C}$, in individual cages with water and specific feed ad libitum (Guabi ${ }^{\circledR}$ Nutrição Animal, Anápolis, Brazil). The rabbits went through an adaptation period of 15 days, undergoing a full physical exam, worming prevention $(0.2 \mathrm{mg} / \mathrm{kg} / 1 \%$ ivermectin, Ceva Sante Animale Group, São Paulo, Brazil), and blood sampling for hemogram to ensure their health. To minimize the animal's stress and discomfort, the staff was trained to follow the rules and schedules for handling rabbits and management of the animal facilities throughout the study.

To induce wounds, all animals were administered $1 \mathrm{mg} / \mathrm{kg}$ of $2 \%$ xylazine (CALMIUN ${ }^{\circledR}$, Agener Animal Health, São Paulo, Brazil) and $1 \mathrm{mg} / \mathrm{kg}$ of $1 \%$ morphine sulfate $\left(1 \%\right.$ DIMORF $^{\circledR}$, Cristália Products, São Paulo, Brazil), both by muscle infusion (IM). Vein catheterization was performed (24G catheter, BD Insyte ${ }^{\mathrm{TM}}$ AutoGuard $^{\mathrm{TM}}$, São Paulo, Brazil) and the anesthetic induction was managed with 10 $\mathrm{mg} / \mathrm{kg}$ of $1 \%$ propofol (PROPOVAN ${ }^{\circledR}$, Cristália Products, São Paulo, Brazil). The animals were intubated and kept under anesthesia by inhalation of isoflurane (ISOFLUORANO ${ }^{\circledR}$, Cristália Products, São Paulo, Brazil) and $100 \%$ oxygen at the rate of $40 \mathrm{~mL} / \mathrm{kg}$ of current volume. A trichotomy and an antisepsis evaluation were performed in the dorsal region of the animals with topical chlorhexidine (Topical Chlorhexidine, Farmogral, Brasília, Brazil). Four wounds were induced using a $1-\mathrm{cm}-$ diameter surgical punch, at specific areas in the back of each animal (Figure 1), up to the exposure of the aponeurosis of muscles. The rabbits were kept with an Elizabethan bung to avoid self-mutilation, licking, and biting, which could contaminate the wound or remove the applied topical medication. Tramadol hydrochloride at $1 \mathrm{mg} / \mathrm{kg} / \mathrm{SC}\left(\right.$ Pfizer $^{\circledR}$, São Paulo, Brazil) was applied until 3 days after the induction of the lesions to control pain.

To evaluate the therapeutic effectiveness of the creams, four groups were established $(n=5)$, including QC, BC, AC, and NC. Each one of the four lesions in the animals received one application during 21 days in a previously defined pattern by drawing. The wounds were washed with $0.9 \%$ sodium chloride solution, instilled under pressure provided by $25 \times 8$ gauge hypodermic needle, attached to a $20-\mathrm{mL}$ syringe and the creams were applied with the aid of disposable spatulas (MARTINS, 2000). The AC and NC groups were the positive and negative controls, respectively, administered allantoin (MARTINS NETO, 2005) and no treatment, respectively. 
Figure 1. Distribution of the skin wounds in the rabbits dorsal region. W1) left cranial paramedial; W2) right cranial paramedial; W3) left caudal paramedical; and W4) right caudal paramedial.

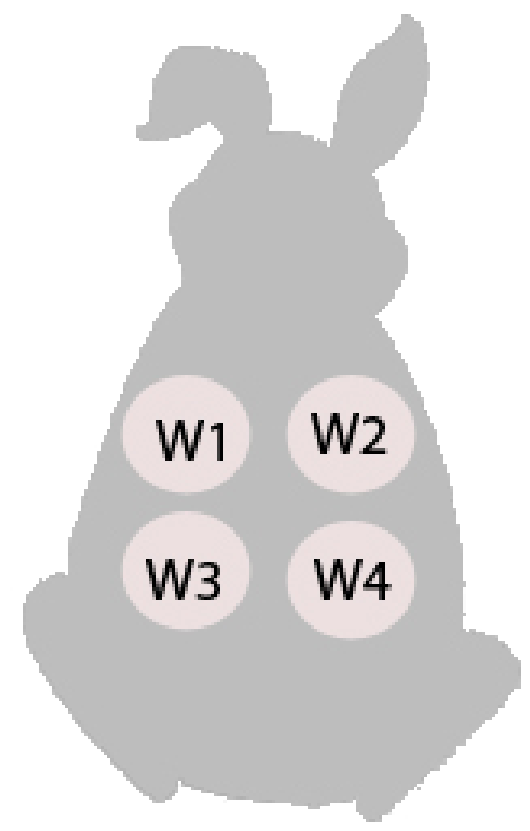

The macroscopic and microscopic analysis of the evolvement of the wound healing process was the fourth stage of the research, including observations during daily clinical examination like redness, hemorrhage, discharge, crusting, and re-epithelialization. Four biopsies of the wounds were carried out in the pre-established periods for microscopic evaluation (Table 1). The animals were anesthetized by a procedure identical to the induction of the wounds and the antisepsis inspection of the adjacent areas to the wounds was performed. Using scalpel and scissors, a skin fragment with totality of the lesion and margin of $1 \mathrm{~cm}$ of intact tissue was retrieved, reaching deep up to the exposure of the aponeurosis of the back muscles. The edges of the lesion were sutured and the animals were assisted up to their clinical recovery, available to be used in other studies.

Table 1. Days biopsies and number of wounds retrieved by group in each one of the intervals proposed for histopathological evaluation.

\begin{tabular}{cccccc}
\hline \multirow{2}{*}{ Days biopsies } & \multicolumn{7}{c}{ Wounds (n)/Group/Interval } & Total \\
\cline { 2 - 5 } & QC & BC & AC & NC & T0 \\
\hline 3rd day & 5 & 5 & 5 & 5 & $\mathbf{2 0}$ \\
7th day & 5 & 5 & 5 & 5 & $\mathbf{2 0}$ \\
14th day & 5 & 5 & 5 & 5 & $\mathbf{2 0}$ \\
21 st day & 5 & 5 & 5 & 5 & $\mathbf{8 0}$ \\
Total of samples & $\mathbf{2 0}$ & $\mathbf{2 0}$ & $\mathbf{2 0}$ & $\mathbf{2 0}$ & \\
\hline
\end{tabular}


The biopsy samples were fixed in $10 \%$ tamponade formaldehyde for 24 hours, processed, embedded in paraffin, sectioned at $5 \mathrm{~mm}$, and stained by hematoxylin and eosin (HE) and Masson's trichrome (MT) techniques. The microscopic analysis of the material was performed blindly by a single observer using the bright field optical microscope and following the criteria adapted from Martins Neto et al. (2003). The histological field of each slide was evaluated using magnifications of $5 \mathrm{x}, 10 \mathrm{x}$, and $40 \mathrm{x}$. The variables analyzed in the HE staining included the serocellular crust (necrosis/crust) and granulation tissue, evaluated as absent and present. The polymorphonuclear and mononuclear infiltrate, fibroblast proliferation, and neovascularization were classified as absent (0), discrete (1), moderate (2), and intense (3). The re-epithelialization was evaluated as absent, partial, and total. The MT staining was used for the collagen analysis.

Data from the macroscopic evaluations went through descriptive analysis. The U-Mann-Whitney test was applied for the microscopic evaluation, considering the significance level at 5\%.

\section{Results and Discussion}

The skin wounds evolved equally up to the $4^{\text {th }}$ day of treatment regardless of the group, with the prevalence of adjacent hyperemia, hemorrhage, serous exudate, and crusting. Then, these signs regressed and were no longer observed in the QC and $\mathrm{BC}$ groups from the $8^{\text {th }}$ day. Hyperemia and exudate were observed in $40 \%$ of the wounds treated with $\mathrm{AC}$ and $\mathrm{NC}$ until the conclusion of the study.

In general, all the wounds developed crusts from the $2^{\text {nd }}$ day; this was attributed to the exudate, cellular debris, and the residual content of the creams applied to the lesions. The crusts would spontaneously detach after re-epithelialization or occasionally during wound antisepsis with sodium chloride solution.

Centripetal retraction occurred in $100 \%$ of the wounds of BC group animals on the $3^{\text {rd }}$ day of evaluation, while in the QC group, the same was observed from the $4^{\text {th }}$ day. The retraction in groups $\mathrm{AC}$ and $\mathrm{NC}$ was observed at days 6 and 8, respectively.

At the $14^{\text {th }}$ day, tissue integrity was restored in $80 \%$ of the BC group wounds and $60 \%$ in group QC. On the $17^{\text {th }}$ and $19^{\text {th }}$ day, all the lesions of BC and QC groups, respectively, were reepithelized. The re-epithelialization in groups $\mathrm{AC}$ and $\mathrm{NC}$ occurred only in $40 \%$ of the wounds in each group at the conclusion of the study.

The scores for the different polymorphonuclear and mononuclear infiltrate, neovascularization, fibroblast proliferation, collagen, and tissue reepithelialization variables were microscopically observed between the groups at different evaluation intervals (Table 2).

The comparative analysis between QC and $\mathrm{BC}$ as well as between these and the other treatments showed differences concerning the polymorphonuclear infiltrate (Figure $2 \mathrm{~A} 1$ ) in the $\mathrm{NC}$ group in relation to $\mathrm{QC}$ and $\mathrm{BC}$ groups at all times, with the infiltrate being higher in NC.

On days 14 and 21, high polymorphonuclear infiltration was observed in the wounds of group $\mathrm{AC}$, and this difference was significant compared to that observed for QC and BC groups (Table 2).

Neovascularization was observed at the first evaluation and persisted during the other study periods in greater or lesser degree in the wounds of the different treatments, with no difference between the wounds of the NC group and those of the QC and $\mathrm{BC}$ treatments at all times (Table 2 and Figure $2 \mathrm{~A} 2)$.

There was less fibroblast proliferation in the wounds of AC and $\mathrm{NC}$ in comparison to those of QC and $\mathrm{BC}$ on days 3 and $7(\mathrm{p}>0.05)$. On the $14^{\text {th }}$ day, the lesions of $\mathrm{NC}$ group showed higher fibroblast proliferation in relation to those of QC and $\mathrm{BC}$, but a statistical difference ( $\mathrm{p}>0.05$ ) was detected only on the $21^{\text {st }}$ day (Table 2 and Figure 2 A2). 
Table 2. Distribution of wounds according to the scores applied to the variables polymorphonuclear and mononuclear infiltrate, neovascularization, fibroblast proliferation, collagen, necrosis/crust, granulation tissue, and reepithelialization for the groups at the 3rd, 7th, 14th, and 21st days, after the induction of the wounds.

\begin{tabular}{|c|c|c|c|c|c|c|c|c|c|c|c|c|c|c|c|c|c|c|c|c|c|c|c|c|c|c|c|c|}
\hline \multirow{2}{*}{ Days } & \multirow{2}{*}{ Group } & \multicolumn{4}{|c|}{ PI } & \multicolumn{4}{|c|}{ MI } & \multicolumn{4}{|c|}{ NV } & \multicolumn{4}{|c|}{ FP } & \multicolumn{4}{|c|}{ CL } & \multicolumn{2}{|c|}{$\mathrm{N} / \mathrm{C}$} & \multicolumn{2}{|c|}{ GT } & \multicolumn{3}{|c|}{ REE } \\
\hline & & A & $\mathrm{D}$ & $\mathrm{M}$ & I & A & $\mathrm{D}$ & $M$ & I & A & $\mathrm{D}$ & $M$ & I & A & $\mathrm{D}$ & $\mathrm{M}$ & I & A & $\mathrm{D}$ & $\mathrm{M}$ & I & $\mathrm{A}$ & $\mathrm{P}$ & $\mathrm{A}$ & $\mathrm{P}$ & $\mathrm{A}$ & $\mathrm{F}$ & $\mathrm{T}$ \\
\hline \multirow[b]{2}{*}{3} & $\mathrm{QC}(\mathrm{n}=5)$ & 0 & 0 & 5 & 0 & 5 & 0 & 0 & 0 & 0 & 5 & 0 & 0 & 0 & 5 & 0 & 0 & 3 & 2 & 0 & 0 & 0 & 5 & 0 & 5 & 5 & 0 & 0 \\
\hline & $\mathrm{BC}(\mathrm{n}=5)$ & 0 & 0 & 4 & 1 & 5 & 0 & 0 & 0 & 0 & 5 & 0 & 0 & 0 & 5 & 0 & 0 & 3 & 2 & 0 & 0 & 0 & 5 & 0 & 5 & 5 & 0 & 0 \\
\hline \multirow{2}{*}{ days } & $\mathrm{AC}(\mathrm{n}=5)$ & 0 & 0 & 4 & 1 & 5 & 0 & 0 & 0 & 0 & 5 & 0 & 0 & 4 & 1 & 0 & 0 & 5 & 0 & 0 & 0 & 0 & 5 & 0 & 5 & 5 & 0 & 0 \\
\hline & $\mathrm{NC}(\mathrm{n}=5)$ & 0 & 0 & 0 & 5 & 5 & 0 & 0 & 0 & 5 & 0 & 0 & 0 & 5 & 0 & 0 & 0 & 5 & 0 & 0 & 0 & 0 & 5 & 0 & 5 & 5 & 0 & 0 \\
\hline \multirow{4}{*}{$\begin{array}{c}7 \\
\text { days }\end{array}$} & $\mathrm{QC}(\mathrm{n}=5)$ & 0 & 0 & 4 & 1 & 5 & 0 & 0 & 0 & 0 & 1 & 4 & 0 & 0 & 0 & 2 & 3 & 1 & 3 & 1 & 0 & 0 & 5 & 0 & 5 & 3 & 2 & 0 \\
\hline & $\mathrm{BC}(\mathrm{n}=5)$ & 0 & 2 & 3 & 0 & 5 & 0 & 0 & 0 & 0 & 0 & 5 & 0 & 0 & 0 & 1 & 4 & 1 & 2 & 2 & 0 & 0 & 5 & 0 & 5 & 0 & 5 & 0 \\
\hline & $\mathrm{AC}(\mathrm{n}=5)$ & 0 & 0 & 5 & 0 & 5 & 0 & 0 & 0 & 0 & 1 & 4 & 0 & 0 & 0 & 5 & 0 & 1 & 4 & 0 & 0 & 0 & 5 & 0 & 5 & 5 & 0 & 0 \\
\hline & $\mathrm{NC}(\mathrm{n}=5)$ & 0 & 0 & 0 & 5 & 5 & 0 & 0 & 0 & 2 & 3 & 0 & 0 & 2 & 3 & 0 & 0 & 5 & 0 & 0 & 0 & 0 & 5 & 3 & 2 & 5 & 0 & 0 \\
\hline \multirow{4}{*}{14 days } & $\mathrm{QC}(\mathrm{n}=5)$ & 1 & 3 & 1 & 0 & 5 & 0 & 0 & 0 & 1 & 4 & 0 & 0 & 0 & 3 & 2 & 0 & 0 & 0 & 4 & 1 & 5 & 0 & 0 & 5 & 0 & 2 & 3 \\
\hline & $\mathrm{BC}(\mathrm{n}=5)$ & 3 & 2 & 0 & 0 & 5 & 0 & 0 & 0 & 3 & 2 & 0 & 0 & 0 & 3 & 2 & 0 & 0 & 0 & 3 & 2 & 3 & 2 & 0 & 5 & 0 & 1 & 4 \\
\hline & $\mathrm{AC}(\mathrm{n}=5)$ & 0 & 0 & 5 & 0 & 5 & 0 & 0 & 0 & 0 & 4 & 1 & 0 & 0 & 4 & 1 & 0 & 0 & 3 & 2 & 0 & 1 & 4 & 1 & 4 & 0 & 5 & 0 \\
\hline & $\mathrm{NC}(\mathrm{n}=5)$ & 0 & 0 & 4 & 1 & 5 & 0 & 0 & 0 & 0 & 3 & 2 & 0 & 0 & 4 & 1 & 0 & 0 & 4 & 1 & 0 & 0 & 5 & 0 & 5 & 0 & 5 & 0 \\
\hline \multirow{4}{*}{21 days } & $\mathrm{QC}(\mathrm{n}=5)$ & 5 & 0 & 0 & 0 & 5 & 0 & 0 & 0 & 1 & 3 & 1 & 0 & 3 & 2 & 0 & 0 & 0 & 0 & 2 & 3 & 5 & 0 & 3 & 2 & 0 & 0 & 5 \\
\hline & $\mathrm{BC}(\mathrm{n}=5)$ & 5 & 0 & 0 & 0 & 5 & 0 & 0 & 0 & 3 & 2 & 0 & 0 & 4 & 1 & 0 & 0 & 0 & 0 & 1 & 4 & 5 & 0 & 3 & 2 & 0 & 0 & 5 \\
\hline & $\mathrm{AC}(\mathrm{n}=5)$ & 2 & 3 & 0 & 0 & 5 & 0 & 0 & 0 & 0 & 4 & 1 & 0 & 2 & 3 & 0 & 0 & 0 & 0 & 3 & 2 & 5 & 0 & 5 & 0 & 0 & 3 & 2 \\
\hline & $\mathrm{NC}(\mathrm{n}=5)$ & 0 & 4 & 0 & 1 & 3 & 2 & 0 & 0 & 0 & 3 & 2 & 0 & 0 & 2 & 3 & 0 & 0 & 1 & 3 & 1 & 3 & 2 & 2 & 3 & 0 & 3 & 2 \\
\hline
\end{tabular}

QC: chitosan cream, BC: barbatiman cream, AC: allantoin cream; NC: base cream; PI: polymorphonuclear infiltrate, MI: mononuclear infiltrate; NV: neovascularization, FP: fibroblast proliferation; CL: collagen; N/C: necrosis/crust; GT: granulation tissue; REE: reepithelialization; A: absent; D: discrete, M: moderate, I: intense, P: present; F: partial, T: total.

The collagen resulting from fibroblast synthesis was observed from the $7^{\text {th }}$ day and increased at days 14 and 21 (Figure 2 B1/B2), showing less intensity in the wounds of the $\mathrm{NC}$ group when compared with those of QC and BC groups on the $7^{\text {th }}$ day ( $p>0.05$ ). On the $14^{\text {th }}$ day, there was a difference in collagen levels in the groups $\mathrm{QC}$ and $\mathrm{BC}$ in relation to that observed for AC and NC groups (Table 2).

The re-epithelialization was characterized by the epithelial migration of the full edges toward the center of the lesion (Figure $2 \mathrm{C} 1 / \mathrm{C} 2$ ) and there was a difference in the $7^{\text {th }}$ and $14^{\text {th }}$ day considering $\mathrm{AC}$ and NC compared to QC and BC (Table 2).

The other variables considered (necrosis/crust, granulation tissue, and mononuclear infiltrate) did not differ significantly between the treatments at any time considered, as shown in Table 3. The results from the first day of evaluation with therapies based on $\mathrm{QC}$ and $\mathrm{BC}$ were consistent with the findings described for the inflammatory phase of the wound healing process. Macroscopically, hyperemia, hemorrhage, and discharge predominated until the $8^{\text {th }}$ day while microscopically, there was a predominance of polymorphonuclear infiltrate in the evaluations on the $3^{\text {rd }}$ and $7^{\text {th }}$ day. Later, the early absence of these signs was observed for the QC and $\mathrm{BC}$ groups in comparison with the treatment with allantoin and neutral creams. These findings may be related to the anti-inflammatory effectiveness of chitosan and tannin active ingredients and Sezer et al. (2007) and Vieira et al. (2008) have pointed out similar results in the initial phase of healing. 
Table 3. Comparison of the variables polymorphonuclear infiltrate, necrosis/crust, granulation tissue, neovascularization, fibroblast proliferation, collagen, mononuclear infiltrate, and tissue reepithelialization in the groups at 3rd, 7th, 14th, and 21 st days.

\begin{tabular}{cccccccccc}
\hline Periods & Treatment & PI & N/C & GT & NV & FP & CL & MI & REE \\
\hline \multirow{5}{*}{3 days } & QC & $2^{\mathrm{a}}$ & $1^{\mathrm{a}}$ & $0^{\mathrm{a}}$ & $1^{\mathrm{a}}$ & $1^{\mathrm{a}}$ & $0^{\mathrm{a}}$ & $0^{\mathrm{a}}$ & $0^{\mathrm{a}}$ \\
& $\mathrm{BC}$ & $2^{\mathrm{a}}$ & $1^{\mathrm{a}}$ & $0^{\mathrm{a}}$ & $1^{\mathrm{a}}$ & $1^{\mathrm{a}}$ & $0^{\mathrm{a}}$ & $0^{\mathrm{a}}$ & $0^{\mathrm{a}}$ \\
& $\mathrm{AC}$ & $2^{\mathrm{a}}$ & $1^{\mathrm{a}}$ & $0^{\mathrm{a}}$ & $1^{\mathrm{a}}$ & $0^{\mathrm{b}}$ & $0^{\mathrm{a}}$ & $0^{\mathrm{a}}$ & $0^{\mathrm{a}}$ \\
& $\mathrm{NC}$ & $3^{\mathrm{b}}$ & $1^{\mathrm{a}}$ & $0^{\mathrm{a}}$ & $0^{\mathrm{b}}$ & $0^{\mathrm{b}}$ & $0^{\mathrm{a}}$ & $0^{\mathrm{a}}$ & $0^{\mathrm{a}}$ \\
\hline \multirow{5}{*}{7 days } & $\mathrm{QC}$ & $2^{\mathrm{a}}$ & $1^{\mathrm{a}}$ & $1^{\mathrm{a}}$ & $2^{\mathrm{a}}$ & $2^{\mathrm{a}}$ & $1^{\mathrm{a}}$ & $0^{\mathrm{a}}$ & $1^{\mathrm{a}}$ \\
& $\mathrm{BC}$ & $2^{\mathrm{a}}$ & $1^{\mathrm{a}}$ & $1^{\mathrm{a}}$ & $2^{\mathrm{a}}$ & $3^{\mathrm{a}}$ & $1^{\mathrm{a}}$ & $0^{\mathrm{a}}$ & $1^{\mathrm{a}}$ \\
& $\mathrm{AC}$ & $2^{\mathrm{a}}$ & $1^{\mathrm{a}}$ & $1^{\mathrm{a}}$ & $2^{\mathrm{a}}$ & $2^{\mathrm{b}}$ & $1^{\mathrm{a}}$ & $0^{\mathrm{a}}$ & $0^{\mathrm{b}}$ \\
& $\mathrm{NC}$ & $3^{\mathrm{b}}$ & $1^{\mathrm{a}}$ & $0^{\mathrm{a}}$ & $1^{\mathrm{b}}$ & $1^{\mathrm{b}}$ & $0^{\mathrm{b}}$ & $0^{\mathrm{a}}$ & $0^{\mathrm{b}}$ \\
\hline \multirow{5}{*}{14 days } & $\mathrm{QC}$ & $1^{\mathrm{a}}$ & $0^{\mathrm{a}}$ & $1^{\mathrm{a}}$ & $1^{\mathrm{a}}$ & $1^{\mathrm{a}}$ & $2^{\mathrm{a}}$ & $0^{\mathrm{a}}$ & $2^{\mathrm{a}}$ \\
& $\mathrm{BC}$ & $0^{\mathrm{a}}$ & $0^{\mathrm{a}}$ & $1^{\mathrm{a}}$ & $0^{\mathrm{a}}$ & $1^{\mathrm{a}}$ & $2^{\mathrm{a}}$ & $0^{\mathrm{a}}$ & $2^{\mathrm{a}}$ \\
& $\mathrm{AC}$ & $2^{\mathrm{b}}$ & $1^{\mathrm{a}}$ & $1^{\mathrm{a}}$ & $1^{\mathrm{a}}$ & $1^{\mathrm{a}}$ & $1^{\mathrm{b}}$ & $0^{\mathrm{a}}$ & $2^{\mathrm{a}}$ \\
& $\mathrm{NC}$ & $3^{\mathrm{b}}$ & $1^{\mathrm{a}}$ & $1^{\mathrm{a}}$ & $1^{\mathrm{b}}$ & $1^{\mathrm{a}}$ & $1^{\mathrm{b}}$ & $0^{\mathrm{a}}$ & $2^{\mathrm{a}}$ \\
\hline \multirow{5}{*}{21 days } & $\mathrm{QC}$ & $0^{\mathrm{a}}$ & $0^{\mathrm{a}}$ & $0^{\mathrm{a}}$ & $1^{\mathrm{a}}$ & $0^{\mathrm{a}}$ & $3^{\mathrm{a}}$ & $0^{\mathrm{a}}$ & $2^{\mathrm{a}}$ \\
& $\mathrm{BC}$ & $0^{\mathrm{a}}$ & $0^{\mathrm{a}}$ & $0^{\mathrm{a}}$ & $0^{\mathrm{a}}$ & $0^{\mathrm{a}}$ & $3^{\mathrm{a}}$ & $0^{\mathrm{a}}$ & $2^{\mathrm{a}}$ \\
& $\mathrm{AC}$ & $1^{\mathrm{b}}$ & $0^{\mathrm{a}}$ & $0^{\mathrm{a}}$ & $1^{\mathrm{a}}$ & $0^{\mathrm{a}}$ & $2^{\mathrm{a}}$ & $0^{\mathrm{a}}$ & $2^{\mathrm{a}}$ \\
& $\mathrm{NC}$ & $1^{\mathrm{b}}$ & $0^{\mathrm{a}}$ & $1^{\mathrm{a}}$ & $1^{\mathrm{b}}$ & $2^{\mathrm{b}}$ & $2^{\mathrm{a}}$ & $1^{\mathrm{a}}$ & $2^{\mathrm{a}}$ \\
\hline
\end{tabular}

Same letters in the same column do not differ among themselves by the U-Mann Whitney test ( $>>0.05)$. The numerical values of the columns correspond to the medians of each treatment. QC: chitosan cream, BC: barbatiman cream, AC: allantoin cream; NC: base cream; PI: polymorphonuclear infiltrate, MI: mononuclear infiltrate; NV: neovascularization, FP: fibroblast proliferation; CL: collagen; N/C: necrosis/crust; GT: granulation tissue; REE: reepithelialization.

On the other hand, the persistence of hyperemia, secretion, and microscopic signs of acute inflammation in the wounds of the NC group suggest irritant reaction caused by the vehicle used. Studies conducted by Vieira et al. (2008) also mentioned the extension of the inflammatory process in wounds treated with $\mathrm{NC}$ only. Unlike the treatments with $\mathrm{BC}$ and $\mathrm{QC}$, the AC group showed extension of the inflammatory process similar to the NC. This fact can be explained by the lower efficiency of the antiinflammatory mechanism occurred in the allantoin presence, as reported by Martins Neto (2005).

The formation of crusts had partially limited the macroscopic evaluation of the wounds. However, the mechanic debridement of this component was not performed to prevent interference in the formation of new epithelium. A similar procedure was adopted by Eurides et al. (1996) for the same purpose. In contrast, Lopes et al. (2005) promoted the debridement of the lesions at the $10^{\text {th }}$ day after surgery to remove the crusts, claiming that the permanence of such would hinder the interpretation of the clinical findings and the application of the products. Although there were no complications in this research and positive results with $\mathrm{BC}$ and QC creams were obtained, it is possible that the permanence of the crusts has reduced the contact surface of the therapeutic protocols adopted, limiting partially the action of the adjuvant in the healing process, suggesting that the results would be still better in lack of crusts.

The centripetal retraction of the lesions was observed by the $4^{\text {th }}$ day in the wounds of the QC and $\mathrm{BC}$ groups, whereas in the other treatment groups, it was found significant only after the $7^{\text {th }}$ day. This finding was histologically characterized by beginning of skin re-epithelialization. Related to this parameter, granulation tissue, fibroblast proliferation, collagen, and neovascularization were also triggered. Thus, the healing process evolved to the proliferative phase, as the above mentioned features correspond to the parameters described for this phase, confirming the descriptions by Hosgood (2006). 
Figure 2. Photomicrograph of rabbits skin wounds. A1) Polymorphonuclear infiltration at 3rd day after surgery. BC group. HE, 20X objective. A2) Granulation tissue at 7th day. Fibroblastic proliferation (black stars) and neovascularization (white arrow). BC group. HE, 10X objective. B1) Collagen lack in the 3rd day. QC group, MT, 5X objective. B2) Conjunctive tissue with filling of organized and cohesive collagen fibers at 21st day. QC group, MT, 5X objective. C1) Skin showing partial reepithelialization (black arrow) at 7th day. BC group, HE, 5X objective. C2) Full reepithelialization and restoration of the skin annexes (black arrow) at 21st day. BC group, HE, 5X objective.
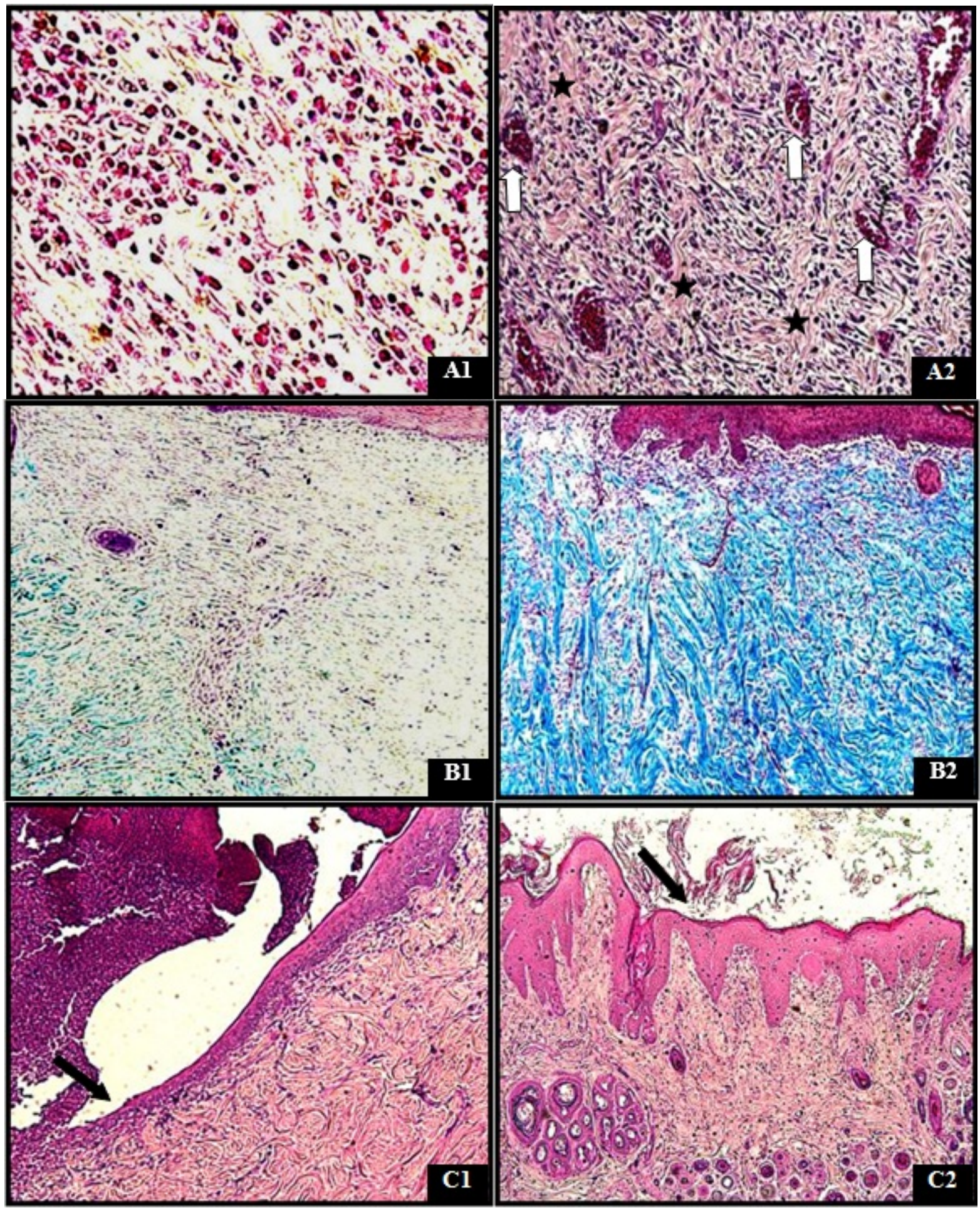
The intensity of fibroblast proliferation at different periods in the wounds of the $\mathrm{AC}$ and $\mathrm{NC}$ groups was less compared to that of QC and $\mathrm{BC}$ groups. Thus, QC and BC stimulated an early and strong fibroblast proliferation, compared to other treatments, where the proliferation occurred much later and for a longer period. Martins et al. (2003) also mentioned that the barbatiman favored the fibroplasia process in the wounds of horses, referring this action to the low oxygen tension and the accumulation of fibrin provided by the phytotherapeutic in the center of the lesion. The immunomodulatory properties of chitosan were confirmed; fibroblast proliferation was marked with this treatment, similar to the results presented by Silva et al. (2006).

The collagen proliferation was also stronger and earlier for the two test groups of the study, QC and BC. Similar results were shown by Lopes et al. (2005), using barbatiman extract, and Sezer et al. (2007), using chitosan films, for the healing of skin wounds in rats and rabbits, respectively. Thus, both treatments play a beneficial role in the collagen proliferation, contributing to the better aspect of the wounds, and providing greater tensile strength of the newly formed tissue.

The neovascularization was stronger between the second and third assessment, regardless of the treatment procedure employed. In addition, by the $21^{\text {st }}$ day, this parameter significantly decreased for all treatment procedures of the study. The presence of newly formed vessels in the early stages favors the dynamics of healing, and according to Barbul (2006), it ensures the supply of nutrients and promotes gas exchange in the microenvironment of the lesion, contributing to the evolution and formation of a healthy new tissue. Moreover, considering the findings of Balbino et al. (2005), it is probable that the formed vessels were apoptotic during the last assessment, a condition that is identified at the end of the healing process. Thus, the angiogenesis to provide the necessary support to the tissue repair process could advance satisfactorily in all groups.
The re-epithelialization was characterized by the migration of the epithelial cells from the intact wound edges towards the center of the lesion. The wounds of the QC and BC groups showed early, full re-epithelialization compared to AC and NC groups, occurring around the $18^{\text {th }}$ day of the treatment. This demonstrates the effectiveness of these protocols as adjuvants in the wound healing process, as well mentioned by Sezer et al. (2007) and Vieira et al. (2008).

\section{Conclusion}

The BC and QC help in the skin repair process and both treatments are effective and economically feasible as adjuvants in the wound healing process.

\section{Acknowledgment}

FAPEG (Foundation for Research Support of Goiás State, Goiânia, Brazil), CNPq (National Council for Technologic and Scientific Development, Brasília, Brazil), Guabi Feed (São Paulo, Brazil), and Agener (Veterinary Products Company, Brasília, Brazil).

\section{References}

ABREU, F. O. M. S.; CAVALCANTE, L. G.; DOUDEMENT, P. V.; CASTRO, A. M.; NASCIMENTO, A. P.; MATOS, J. E. X. Propriedades e características da quitosana obtida a partir do exoesqueleto de CaranguejoUçá utilizando radiação de microondas. Revista Polímeros Ciência e Tecnologia, Fortaleza, v. 23, n. 5, p. 630-635, 2013.

ACKERMAN, M. R. Acute inflammation. In: MC GAVIN, M. D.; ZACHARY, J. F. Pathologic basis veterinary disease. Philadelphia: Mosby Elsevier, 2007. cap. 3-4, p. 101-191.

AFZALETDINOVA, N. G.; MURINOV, Y. I.; MULLAGALIEV, I. R.; ZARUDII, F. S.; DAVYDOVA, V. A.; ISMAGILOVA, A. F. Synthesis and wound healing and antiulcer activity of a chitosan-rhodium (III) complex. Pharmaceutical Chemistry Journal, New York, v. 34, n. 5, p. 26-30, 2000. 
BALBINO, C. A.; PEREIRA, L. M.; CURI, R. Mecanismos envolvidos na cicatrização: uma revisão. Revista Brasileira de Ciências Farmacêutica, São Paulo, v. 41, n. 1, p. 27-51, 2005.

BARBUL, A. History of wound healing. In: BRUNICARDI, F. C.; SEYMOUR, I.; SCHWARTS, D. L.; DUN, D. K.; ANDERSEN, R. E. Schwartz's surgery. Ontario: Companion Handbook, 2006. p. 25-78.

EURIDES, D.; MAZZANTI, A.; BELLETI, M. E.; SILVA, L. A. F. da; FIORAVANTE, M. C. S.; TRONCOSO NETO, N. S.; CAMPOS, V. A.; LEMOS, R. C.; SILVESTRINI JUNIOR, P. L. Morfologia e morfometria da reparação tecidual de feridas cutâneas de camundongos tratadas com solução aquosa de barbatimão (Stryphnodendron barbatiman Martius). Revista da Faculdade de Zootecnia Veterinária e Agronomia de Uruguaína, Uruguaína, v. 2-3, n. 1, p. 37-42, 1996.

GILBERT, B.; FERREIRA, J. L. P.; ALVES, L. F. Monografias de plantas medicinais brasileiras $e$ aclimatadas. Curitiba: Abifito, 2005. 250 p.

HOSGOOD, G. Stages of wound healing and their clinical relevance. The Veterinary Clinics of North America. Small Animal Practice, Philadelphia, v. 36, n. 4, p. 667-685, 2006.

KUMAR, V.; ABBAS, A. K.; FAUSTO, N. Inflammation. In: ROBBINS \& COTRAN. Pathologic basis of disease. $7^{\text {th }}$ ed. Philadelphia: Elsevier Saunder, 2005. cap. 2-3, p. 47-118.

LEE, W. R.; PARK, J. H.; KIM, K. H.; KIM, S. J.; PARK, D. H.; CHAE, M. H.; SUH, S. H.; JEONG, S. W.; PARK, K. K. The biological effects of topical alginate treatment in an animal model of skin wound healing. Wound Repair and Regeneration, Denmark, v. 17, n. 4, p. 505-510, 2009.

LIMA, C. R. O.; RABELO, R. E.; MOURA, V. M. B. D.; SILVA, L. A. F.; TRESVENZOL, L. M. F. Cicatrização de feridas cutâneas e métodos de avaliação. Revisão de literatura. Revista CFMV, Brasília, ano 18, n. 56, p. 5359, 2012.

LOPES, G. C.; SANCHES, A. C.; NAKAMURA, C. V.; DIAS FILHO, B. P.; HERNANDES, L.; MELLO, J. C. de. Influence of extracts of Stryphnodendron polyphyllum Mart. and Stryphnodendron obovatum Benth. on the cicatrisation of cutaneous wound in rats. Journal of Ethnopharmacology, Lausanne, v. 99, n. 2, p. 256-272, 2005.
MARTINS, M. F.; CAETANO, F. A. M.; SÍRIO, O. J.; YIOMASA, M. M.; MIZUSAKI, C. I.; FIGUEIREDO, L. D.; PACHECO, P. Avaliação macro e microscópica da cicatrização de lesões experimentalmente provocadas em pele de coelhos tratadas com secreção mucoglicoproteica do escargot Achatina fulica. Brazilian Journal of Veterinary Research and Animal Science, São Paulo, v. 40, n. 3, p. 213-218, 2003.

MARTINS NETO, A. N. Tratamento tópico com mel, própolis em gel e creme a base de alantoina em feridas experimentalmente infectadas em coelhos. 2005. Dissertação (Mestrado em Medicina Veterinária) Escola de Veterinária, Universidade Federal de Viçosa, Viçosa, MG.

MARTINS, P. A. E. Avaliação de três técnicas de limpeza do sítio cirúrgico infectado utilizando soro fisiológico para remoção de microrganismos. 2000. Dissertação (Mestrado em Enfermagem Fundamental da Escola de Enfermagem) - Universidade de São Paulo, São Paulo.

MOLE, S.; WATERMAN, P. G. A critical analysis of techniques for measuring tannins in ecological studies I. Techniques for chemically defining tannins. Oecologia, Berlin, v. 72, p. 137-147, 1987a.

A critical analysis of techniques for measuring $\overline{\text { tannins }}$ in ecological studies II. Techniques for biochemically defining tannins. Oecologia, Berlin, v. 72, p. 148-156, $1987 \mathrm{~b}$.

SEZER, A. D.; HATIPOGLU, F.; CEVHER, E.; OĞURTAN, Z.; BAS, A. L.; AKBUĞA, J. Chitosan film containing fucoidan as a wound dressing for dermal burn healing: preparation and in vitro / in vivo evaluation. AAPS Pharmscitech, Istanbul, v. 8, n. 2, p. 1- 8, 2007.

SILVA, H. S. R. C.; SANTOS, K. S. C. R.; FERREIRA, E. I. Quitosana: derivados hidrossolúveis, aplicações farmacêuticas e avanços. Química Nova, Campinas, v. 29, n. 4, p. 776-785, 2006.

SILVA, L. A. F.; EURIDES, D.; DE PAULA, J. R.; LIMA, C. R. O.; MOURA, M. I. Manual do barbatimão. Goiânia: Kelps, 2010. 94 p.

VIEIRA, A. P.; SANTOS, N. R.; BORGES, J. H. S.; VINCENZI, M. P. A.; SCHMITZ, W. O. Ação dos flavonóides na cicatrização por segunda intenção em feridas limpas induzidas cirurgicamente em ratos Wistar. Semina: Ciências Biológicas e Saúde, Londrina, v. 29, n. 1, p. 65-74, 2008. 